\title{
Hippocampal Long-Term Potentiation Suppressed by Increased Inhibition in the Ts65Dn Mouse, a Genetic Model of Down Syndrome
}

\author{
Alexander M. Kleschevnikov, ${ }^{1}$ Pavel V. Belichenko, ${ }^{1}$ Angela J. Villar, ${ }^{3}$ Charles J. Epstein, ${ }^{3}$ Robert C. Malenka, ${ }^{2}$ and \\ William C. Mobley ${ }^{1}$ \\ ${ }^{1}$ Department of Neurology and Neurological Sciences, and the Institute for Neuroscience, and ${ }^{2}$ Nancy Pritzker Laboratory, Department of Psychiatry, \\ Stanford University Medical School, Stanford University, Stanford, California 94305, and ${ }^{3}$ Department of Pediatrics, University of California, San Francisco, \\ San Francisco, California 94143
}

\begin{abstract}
Although many genetic disorders are characterized by cognitive failure during development, there is little insight into the neurobiological basis for the abnormalities. Down syndrome (DS), a disorder caused by the presence of three copies of chromosome 21 (trisomy 21 ), is characterized by impairments in learning and memory attributable to dysfunction of the hippocampus. We explored the cellular basis for these abnormalities in Ts65Dn mice, a genetic model for DS. Although basal synaptic transmission in the dentate gyrus was normal, there was severe impairment of long-term potentiation (LTP) as a result of reduced activation of NMDA receptors. After suppressing inhibition with picrotoxin, a GABA receptor antagonist, NMDA receptor-mediated currents were normalized and induction of LTP was restored. Several lines of evidence suggest that inhibition in the Ts65Dn dentate gyrus was enhanced, at least in part, because of presynaptic abnormalities. These findings raise the possibility that similar changes contribute to abnormalities in learning and memory in people with DS and, perhaps, in other developmental disorders with cognitive failure.
\end{abstract}

Key words: Down syndrome; synaptic; presynaptic; inhibition; long-term potentiation; dentate; gyrus; GABAergic

\section{Introduction}

The neurobiological basis for development disorders of cognition is little explored and poorly understood. Down syndrome (DS), a frequent cause of mental and physical disability in children and adults, is attributable to trisomy for chromosome 21 (Epstein, 2002; Roizen and Patterson, 2003). The presence of one extra copy of the $\sim 300$ normal genes on chromosome 21 results in a number of significant clinical phenotypes. Among the most important are those affecting the nervous system. Impairment of cognitive function is nearly universal in DS (Epstein, 2002), with characteristic and specific deficits in learning and memory (Chapman and Hesketh, 2000). Although there is limited insight into the biological basis for the cognitive failure, abnormalities in explicit memory point to involvement of the hippocampus (Carlesimo et al., 1997; Vicari et al., 2000; Pennington et al., 2003). The impairment of this aspect of hippocampally mediated cognition appears to be specific, because the deficit in individuals with DS was more severe than in subjects mentally retarded because of other etiologies (Carlesimo et al., 1997). Additional evidence for abnormalities involving the hippocampus are neuro-

Received May 7, 2004; revised July 26, 2004; accepted July 27, 2004.

This work was supported by grants from the National Institutes of Health (NS 38869, AG 16999, HD 31498), the Hillblom Foundation, and the Down Syndrome Research and Treatment Foundation.

Correspondence should be addressed to Dr. A. M. Kleschevnikov, 1201 Welch Road, Medical School Laboratory Surge Building, Room P220, Stanford University, Stanford, CA 94305-5489. E-mail: akleschevnikov@stanford.edu. DOI:10.1523/JNEUROSCI.1766-04.2004

Copyright $\odot 2004$ Society for Neuroscience $\quad$ 0270-6474/04/248153-08\$15.00/0 imaging studies showing that the volume of the hippocampus, adjusted for brain size, is smaller in individuals with DS than in controls (Aylward et al., 1999; Pinter et al., 2001; Krasuski et al., 2002). Studies exploring the structure and function of the hippocampus will be essential for elucidating the neurobiological basis for cognitive failure in DS.

Mouse models of neurological disorders provide the opportunity to define abnormal cellular mechanisms. Models of DS can be used both to elucidate molecular and cellular pathogenesis and to link these abnormalities to an increased dose of a specific gene(s) (Antonarakis et al., 2001; Dierssen et al., 2001; Reeves et al., 2001; Epstein, 2002). The most useful model of DS, the Ts65Dn mouse, is segmentally trisomic for mouse chromosome 16 and carries three copies of genes orthologous to those on human chromosome 21 (Davisson et al., 1990; Gardiner et al., 2003). The trisomic region extends from Gabpa to $M x 1(\sim 140$ genes) (Gardiner et al., 2003); it overlaps substantially with the region of human chromosome 21 held to be responsible for many DS phenotypes, including mental retardation (Korenberg et al., 1994). Ts65Dn mice exhibit a number of features characteristic of DS, including impairment of hippocampal function as evidenced by impaired spatial memory (Reeves et al., 1995; Demas et al., 1996, 1998; Holtzman et al., 1996; Escorihuela et al., 1998; Sago et al., 2000) and context discrimination (Hyde et al., 2001).

To further explore the function of the hippocampus in Ts65Dn mice, we examined synaptic plasticity in the dentate gyrus (DG) in hippocampal slices. Excessive inhibition of dentate 
granule cells was shown to restrict synaptic activation of NMDA receptors and to inhibit long-term potentiation (LTP). Blocking inhibition restored the NMDA receptor-mediated component of EPSP and LTP. These data are evidence for a marked change in hippocampal synaptic physiology that may contribute to failed performance on cognitive tasks in DS.

\section{Materials and Methods}

Animal husbandry. Segmental trisomy 16 (Ts65Dn) mice were obtained by mating female carriers of the $17^{16}$ chromosome (B6EiC3H-a/ATs65Dn) with $(\mathrm{C} 57 \mathrm{BL} / 6 \mathrm{JEi} \times \mathrm{C} 3 \mathrm{H} / \mathrm{HeJ}) \mathrm{F}_{1}(\mathrm{JAX} \# \mathrm{JR} 1875)$ males (Davisson et al., 1993). Ts65Dn mice are thus maintained on the B6/C3H background. Cultured tail fibroblasts were used for karyotype analysis of metaphase spreads to determine the genotype of each animal according to conventional methods. Ts65Dn and $2 \mathrm{~N}$ control mice were housed three to five per cage with a $12 \mathrm{hr}$ light/dark cycle and ad libitum access to food and water. Experimental male mice were 3-4 months of age.

Slice preparation. Mice were anesthetized with isoflurane before decapitation. The brain was quickly removed and immersed for 2-3 min in ice-cold artificial CSF (ACSF) [containing (in mM): $119 \mathrm{NaCl}, 2.5 \mathrm{KCl}$, $2.5 \mathrm{CaCl}_{2}, 1.3 \mathrm{MgSO}_{4}, 1 \mathrm{NaH}_{2} \mathrm{PO}_{4}, 26 \mathrm{NaHCO}_{3}$, and 10 glucose], osmolarity 310 , continuously bubbled with $95 \% \mathrm{O}_{2}$ and $5 \% \mathrm{CO}_{2}$, $\mathrm{pH}$ 7.4. The hippocampus was extracted and cut in ice-cold ACSF with a vibratome (Leica 1000; Leica, Nussloch, Germany) into 350- $\mu$ m-thick transverse slices, which were allowed to recover in oxygenated ACSF at $32^{\circ} \mathrm{C}$ for 30 min, and then at room temperature for an additional 1-10 hr before experimental recordings. In experiments using whole-cell recordings, the slicing of hippocampus was performed in solution containing (in mM): 250 sucrose, $2.5 \mathrm{KCl}, 1.3 \mathrm{CaCl}_{2}, 2.5 \mathrm{MgSO}_{4}, 1 \mathrm{NaH}_{2} \mathrm{PO}_{4}, 26$ $\mathrm{NaHCO}_{3}$, and 10 glucose (Moyer and Brown, 1998). All of the experiments were conducted in accordance with the National Institutes of Health guidelines for the care and use of animals and with an approved animal protocol from the Stanford University Institutional Animal Care and Use Committee.

Recording of evoked field potentials. A slice was transferred into the recording chamber and superfused with ACSF at a constant rate of 2.5 $\mathrm{ml} / \mathrm{min}$ at a temperature of $32^{\circ} \mathrm{C}$. Recording and stimulating electrodes were made of borosilicate glass capillaries (1B150F; World Precision Instruments, Sarasota, FL) and filled with $2 \mathrm{M} \mathrm{NaCl}$ (resistance, $0.3-0.5$ $\mathrm{M} \Omega$ ). Under visual control, the stimulating electrode was inserted into the middle molecular layer (MML), and the recording electrode was inserted into either the MML or the granule cell layer of the DG upper blade. The stimulating and recording electrodes were separated by a distance of $300-350 \mu \mathrm{m}$. If not specified otherwise, testing stimuli evoked field EPSPs (fEPSPs) that were 70-90\% of maximum. The magnitude of the fEPSP was measured as the initial slope of the linear part of the fEPSP, which occurred $0.1-1 \mathrm{msec}$ after the presynaptic volley (see Fig. $2 \mathrm{~A}$ ). The amplitude of the fEPSP was measured at the maximum, averaging over a $0.4 \mathrm{msec}$ window. The amplitude of the population spike was measured as follows: (1) a line was drawn at the base of the population spike connecting the first and second peaks of the field response, (2) a second line was drawn at the peak of the population spike (i.e., at the peak of the downward deflection), and (3) at the peak of the spike, a line was drawn vertically between these two lines, thus giving the amplitude of the population spike (see Fig. $5 A$ ). LTP was induced by tetanization with three trains of stimuli ( $1 \mathrm{sec}$ at $100 \mathrm{~Hz}$; 5 min between the trains). In the experiments using picrotoxin, a single tetanization (1 sec; $100 \mathrm{~Hz}$ ) was used.

To measure the contribution of NMDA receptors to fEPSP, a modified ACSF was used. This solution contained 2,3-dioxo-6-nitro-1,2,3,4tetrahydrobenzoquinoxaline-7-sulfonamide (NBQX) $(0.2 \mu \mathrm{M})$ to partially ( $\sim 50 \%)$ suppress AMPA receptors (data not shown), glycine (15 $\mu \mathrm{M})$, an agonist at the glycine-binding site of NMDA receptors, and a reduced concentration of $\mathrm{Mg}^{2+}(0.6 \mathrm{~mm})$ (Bayazitov and Kleschevnikov, 2000). Three stimuli $(100 \mathrm{~Hz})$ were used to assess synaptic activation of the NMDA receptors by high-frequency afferent stimulation. Only two stimuli were delivered when the NMDA receptor-mediated component of fEPSP was measured under picrotoxin, because enhanced excitability of granule cells provoked epileptic-like activity. After stabilization of the responses, an antagonist of NMDA receptors, DL-2-amino-5phosphonovaleric acid (DL-APV) $(40 \mu \mathrm{M})$, was applied for $10 \mathrm{~min}$. The responses recorded under these conditions were taken as the AMPA receptor-mediated component of the fEPSP. The NMDA receptormediated component of the fEPSP was then computed as the difference between the responses recorded before and during the application of DL-APV. The magnitudes of the AMPA and NMDA receptor-mediated responses were measured at the maximum, averaging over a $0.4 \mathrm{msec}$ window for the AMPA response and a $1.2 \mathrm{msec}$ window for the NMDA response.

Whole-cell recordings. Whole-cell recordings were performed from DG granule cells using an Axoclamp-2A amplifier (Axon Instruments, Foster City, CA). The recording electrodes were filled with a solution containing (in mM): $135 \mathrm{CsCl}, 2 \mathrm{MgCl}_{2}$, 2.5 EGTA, 10 HEPES, $2 \mathrm{MgATP}, 0.2 \mathrm{Na}_{2}$ GTP, and 2 lidocaine $N$-ethyl bromide, osmolarity 290, pH 7.3. EPSCs were evoked by stimulating with a glass micropipette positioned in the MML at a distance of $150-300 \mu \mathrm{m}$ from the recording cell. IPSCs were evoked with a micropipette positioned on the border between the inner molecular layer and MML (40-50 $\mu \mathrm{m}$ from the granule cell layer). The recordings were filtered at $3 \mathrm{kHz}$, digitized at $5 \mathrm{kHz}$, and stored in a computer. Paired stimuli were used to assess paired-pulse facilitation (PPF) of evoked IPSCs (eIPSCs). In these experiments, the concentration of calcium in ACSF was reduced to $0.8 \mathrm{~mm}$, and the concentration of magnesium was increased to $3.0 \mathrm{~mm}$. The amplitude of the first eIPSC was measured as the distance between the response maximum and the baseline for the recording; the amplitude of the second eIPSC was measured as the distance between the response maximum and the trace that corresponded to the first response when a single stimulus was applied (see Fig. 7A). Miniature IPSCs (mIPSCs) were recorded in ACSF containing $1 \mu \mathrm{M}$ NBQX, $25 \mu \mathrm{M}$ D-APV, and $1 \mu \mathrm{M}$ TTX. The frequency, amplitude, and duration of mIPSCs were evaluated with use of the program MiniAnalysis (Synaptosoft, Decatur, GA).

For all of the experiments, data are presented as mean \pm SEM ( $n$ is number of slices). Mann-Whitney $U$ test was used to examine the differences in the tetanization-induced responses in $2 \mathrm{~N}$ and Ts65Dn dentate gyrus. In all of the other comparisons, the $t$ test was used, and $p<0.05$ was considered to be statistically significant.

\section{Results}

Basal synaptic transmission is normal in the dentate gyrus in Ts65Dn mice

To assess synaptic function in the DG, we examined evoked fEPSPs in the MML of $2 \mathrm{~N}$ (i.e., normal) and Ts65Dn mice. The responses to individual stimuli (Fig. $1 A$ ) and the dependence of the initial slope of fEPSPs on stimulating current (Fig. $1 B$ ) were essentially normal in slices from Ts65Dn mice. In addition, there was no difference in the dependence of the initial slope of fEPSPs on the amplitude of the presynaptic volley (Fig. 1C). Paired-pulse ratios of fEPSP amplitudes at interstimulus intervals ranging from $10 \mathrm{msec}$ to $10 \mathrm{sec}$ were also normal in the Ts65Dn mice (Fig. $1 D)$. These findings suggest that basal excitatory synaptic transmission is normal in the DG of Ts65Dn mice.

\section{Failed induction of LTP and inadequate synaptic activation of NMDA receptors in Ts65Dn mice}

LTP is a well studied synaptic model of learning and memory (Malenka and Nicoll, 1999). In control 2N mice, LTP in the MML of the DG was elicited using tetanic stimulation $(100 \mathrm{~Hz}$; $1 \mathrm{sec}$ train given three times, 5 min apart) $(123.7 \pm 4.5 \%$ of baseline; $n=9 ; p<0.01$ ) (Fig. 2). In contrast, LTP was not induced in slices from Ts65Dn mice $(103.7 \pm 2.4 \% ; n=8 ; p>$ $0.15)$. The difference between $2 \mathrm{~N}$ and Ts65Dn slices was apparent soon after the tetanic stimulation and persisted throughout the duration of the experiment. To determine whether or not LTP could be induced with a stronger tetani- 
A

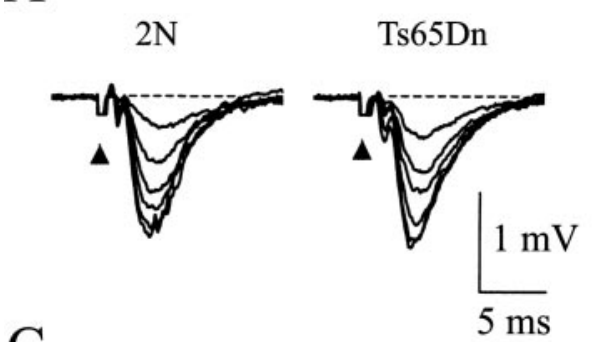

$\mathrm{C}$

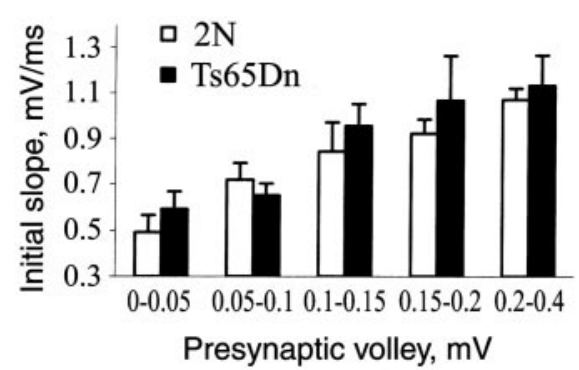

B
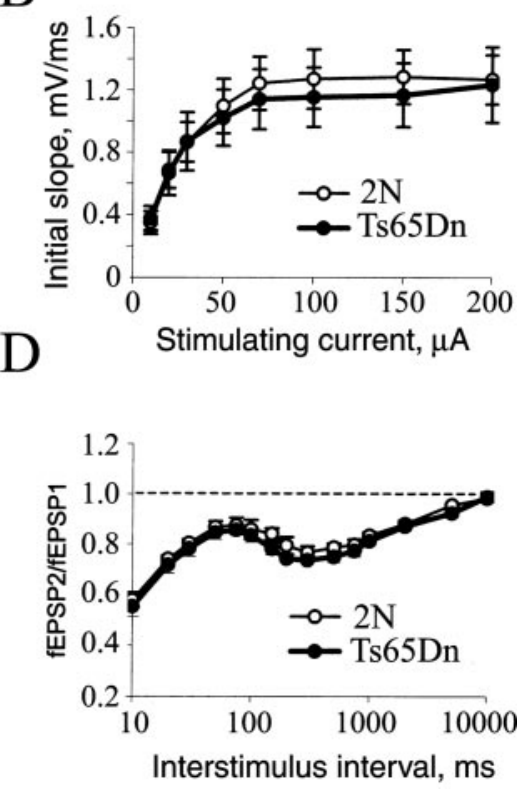

To address the mechanism responsible for the failed LTP in Ts65Dn mice, we first examined whether synaptic activation of NMDA receptors was normal using fEPSP recordings. The NMDA receptordependent component of the fEPSP was isolated by computing the difference in the responses to a three stimuli train (given at $100 \mathrm{~Hz}$ ) before and after application of the NMDA receptor antagonist DLAPV $(40 \mu \mathrm{M})$ (Fig. $3 A)$. After the second and the third stimuli in the train, the NMDA receptor-mediated component of the fEPSP, when normalized to the AMPA receptor-mediated component, was significantly smaller in the Ts65Dn slices when compared with that in $2 \mathrm{~N}$ slices (Fig. $3 B)(p<0.03)$. Decreased synaptic activation of NMDA receptors was a likely proximate cause for the failure to induce LTP in Ts65Dn.

The reduction of the NMDA receptormediated component of the fEPSP in Ts65Dn slices could be attributable to inadequate depolarization of the postsynaptic neurons during the high-frequency stimulation or to alterations in the number or properties of the synaptic NMDA receptors. To distinguish these possibilities, we examined fEPSPs in magnesium-

A

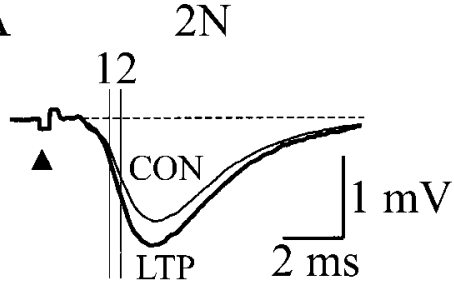

B

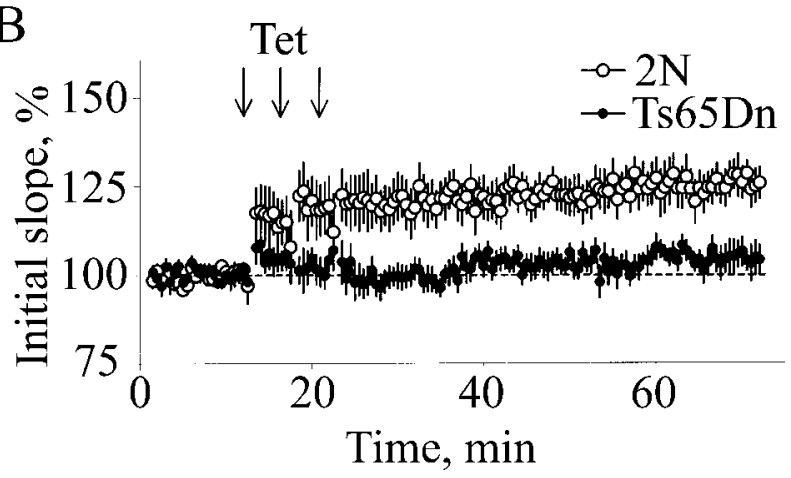

Figure 2. LTP is absent in the Ts65Dn DG. A, Representative evoked fEPSPs recorded from slices of $2 \mathrm{~N}$ (left) and Ts65Dn mice (right) before (CON) and 50 min after (LTP) tetanization (thin and thick lines, respectively). Arrowheads denote stimulus artifacts that have been truncated. The vertical lines (labeled 1 and 2 ) indicate the interval used for the measuring the initial slope. Note the increase in the initial slope for the 2N but not the Ts65Dn DG. Each curve represents an average of five consecutive responses. $B$, Time course of the averaged initial slope of the fEPSP. A series of three tetanizations (arrows; Tet) applied at 5 min intervals evoked stable LTP in 2N, but failed to induce LTP in the Ts65Dn DG (open and filled circles, respectively).

zation, in a separate series of experiments, five trains of stimuli ( $1 \mathrm{sec} ; 100 \mathrm{~Hz}$ ) were applied. Although LTP was induced in $2 \mathrm{~N}$ slices $(135.8 \pm 5.1 \% ; n=3)$, it was not induced in Ts65Dn slices $(99.5 \pm 3.3 \% ; n=6)$.

free ACSF, in which inadequate depolarization during the train should no longer restrict current flow through the NMDA receptors. Under these conditions, no difference between $2 \mathrm{~N}$ and Ts65Dn slices was apparent in the calculated NMDA receptormediated components of the fEPSP (Fig. 3C,D). To further examine whether NMDA receptor-mediated synaptic currents are normal in Ts65Dn dentate granule cells, we performed whole-cell voltage-clamp recordings. First, the AMPA receptor-mediated synaptic current was recorded at a holding potential of $-80 \mathrm{mV}$. Then, recording from the same cell, the AMPA receptor antagonist NBQX $(10 \mu \mathrm{M})$ was applied and the NMDA receptormediated current was recorded at a holding potential of $+40 \mathrm{mV}$ (Fig. 3E). The calculated ratio of NMDA receptor-mediated to AMPA receptor-mediated synaptic currents, which controls for slice-to-slice variability in the number of synapses activated (Saal et al., 2003), was not different between $2 \mathrm{~N}$ and Ts65Dn mice (Fig. $3 F$ ). Together, these results indicate that NMDA receptormediated transmission is normal in Ts65Dn mice. Thus, the difference in the NMDA receptor-mediated component of the fEPSP in normal ACSF likely arises from inadequate depolarization of the postsynaptic granule cells by trains of afferent stimuli.

\section{Suppressing inhibition normalizes LTP in Ts65Dn mice}

Because basal excitatory synaptic transmission appeared normal in Ts65Dn mice, we reasoned that increased inhibition could account for the abnormalities in the NMDA receptor-mediated component of the fEPSP and LTP. To test this possibility, fEPSPs evoked by two stimuli (given at $100 \mathrm{~Hz}$ ) were recorded before and after application of DL-APV in the presence of normal ACSF containing the $\mathrm{GABA}_{\mathrm{A}}$ receptor antagonist picrotoxin $(100 \mu \mathrm{M})$ (Fig. $4 A$ ). This suppression of inhibition eliminated the difference in the NMDA receptor-mediated component of the fEPSP between $2 \mathrm{~N}(n=7)$ and Ts65Dn $(n=8)$ slices (Fig. $4 A, B)(p>0.5)$. 
A

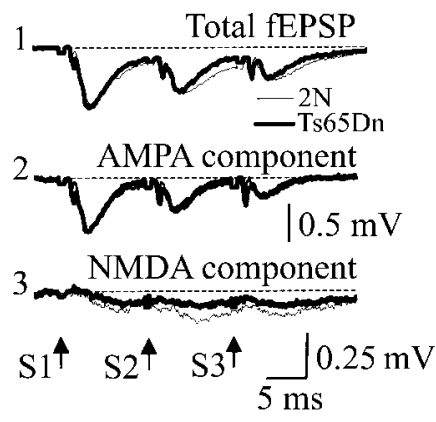

$\mathrm{C}$

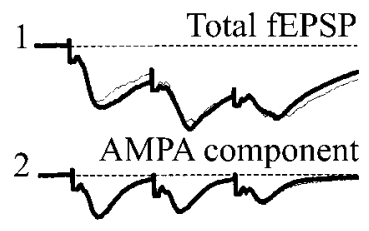

NMDA component
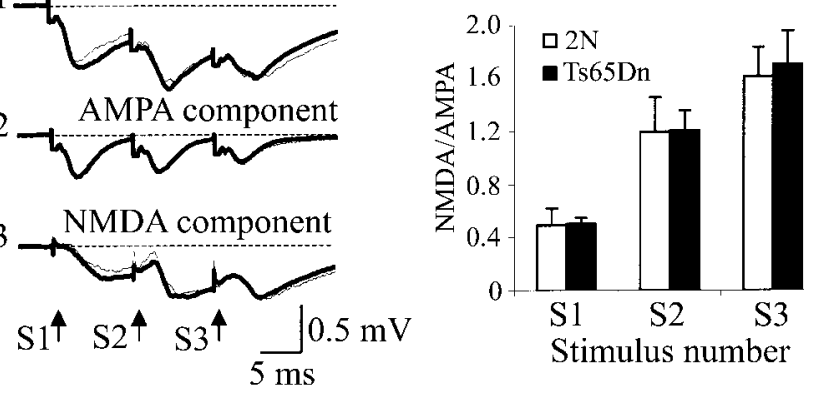

B

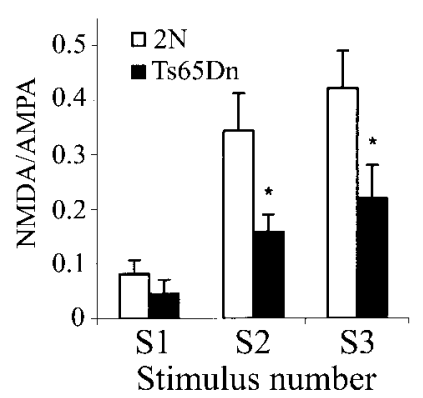

$\mathrm{D}$

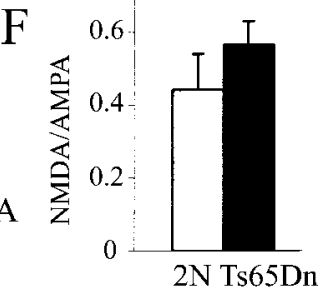

Figure 3. Inadequate synaptic activation of NMDA receptors in the Ts65Dn DG is normalized by removing extracellular magnesium or depolarization. $A$, Representative field responses evoked by a three-stimulus (arrowheads; S1, S2, and S3), $100 \mathrm{~Hz}$ train in the 2N and Ts65Dn DG (thin and thick lines, respectively). 1, fEPSPs recorded in modified ACSF before application of APV. Note after the second and the third stimuli the difference in the late phases of the responses. 2, The AMPA receptor-dependent component of fEPSP recorded in an APV-containing solution. 3, The NMDA receptor-dependent component of the responses calculated as the difference in the responses recorded before and during application of APV (i.e., " 1 " minus " 2 "). $B$, Averaged ratios of the NMDA-AMPA responses evoked by each of the three stimuli. The ratio was significantly smaller in the Ts65Dn DG for the second and the third stimuli. ${ }^{*} p<0.03$. C, fEPSPs evoked by three-stimuli trains in magnesium-free modified ACSF. Total fEPSPs recorded before application of APV (1), and the AMPA receptor-mediated component of fEPSPs recorded after suppression of the NMDA receptors with APV (2), were indistinguishable in the $2 \mathrm{~N}$ and Ts65Dn DG. Consequently, the NMDA receptor-mediated component of fEPSPs, taken as "1" minus " 2, " were also indistinguishable (3). D, Averaged ratios of the amplitudes of NMDAAMPA receptor-mediated components of fEPSP in magnesium-free ACSF. There was no difference between the $2 \mathrm{~N}$ and Ts65Dn DG. E, Whole-cell currents recorded in the DG of slices from $2 \mathrm{~N}$ and Ts65Dn mice at holding potentials of -80 and $+40 \mathrm{mV}$. The responses at $-80 \mathrm{mV}$ reflect activation of AMPA receptors. The responses at $+40 \mathrm{mV}$ reflect activation of NMDA receptors, because at this holding potential, AMPA receptors were blocked by application of NBQX. $F$, Ratios of the amplitudes of the whole-cell currents recorded at +40 and $-80 \mathrm{mV}$. The NMDA receptor-dependent responses were similar in the $2 \mathrm{~N}$ and Ts65Dn DG. Open bar, $2 \mathrm{~N}$; filled bar, Ts65Dn. The error bars in $B, D$, and $F$ represent SEM.

We then proceeded to test whether suppression of inhibition would allow induction of LTP in Ts65Dn slices. In the presence of picrotoxin, tetanic stimulation induced normal LTP in Ts65Dn slices $(2 \mathrm{~N}, 119.2 \pm 4.1 \% ; n=8$; Ts65Dn, $123.9 \pm 9.2 \% ; n=8$; $p>0.5$ ) (Fig. 4C). Together, these findings suggest that excessive
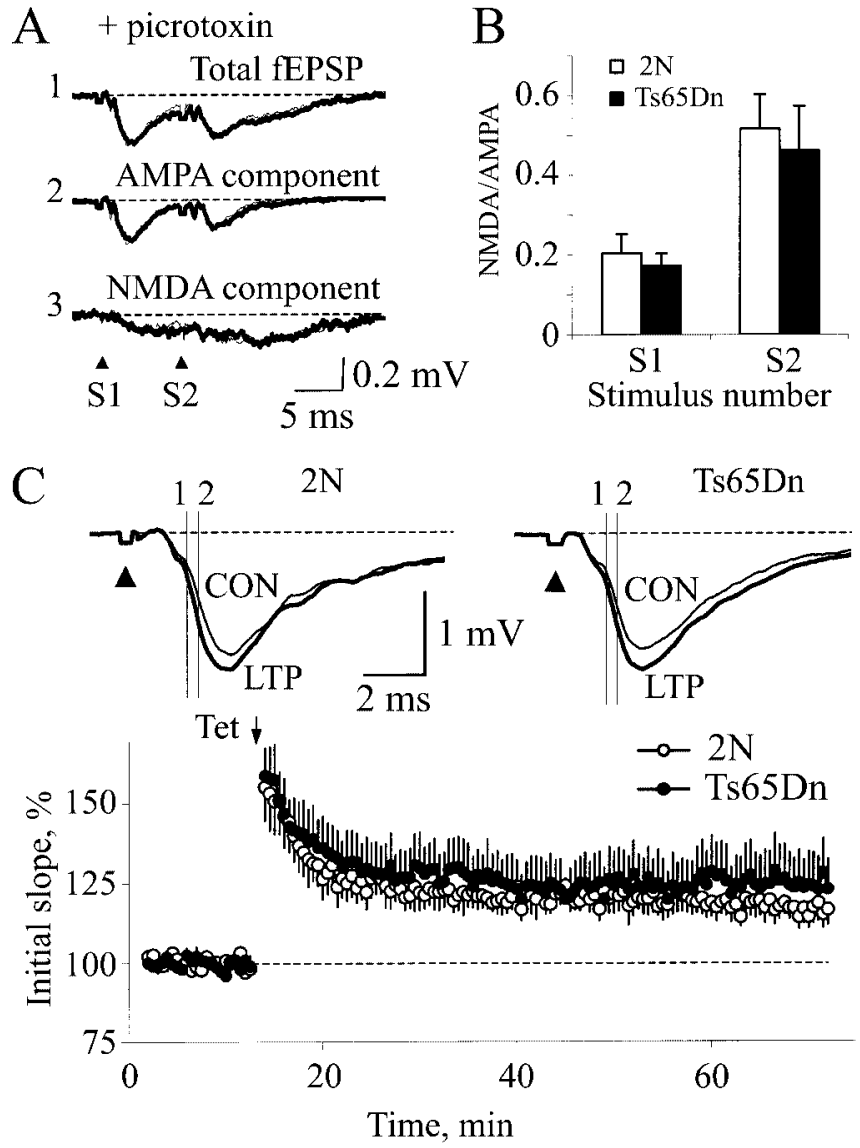

Figure 4. Suppressing inhibition in the Ts65Dn DG restores both the NMDA receptormediated component of the fEPSP and LTP. A, Field responses in slices from 2N and Ts65Dn mice (thin and thick lines, respectively) recorded in ACSF containing picrotoxin. 1, Responses recorded before application of APV. 2, The AMPA receptor-mediated components of fEPSP recorded after suppression of NMDA receptors with APV. 3, The NMDA receptor-mediated component calculated as the difference between " 1 " and "2" (i.e., "1" minus " 2 "). B, Ratio of the amplitudes of NMDA-AMPA receptor-mediated components of fEPSP. There was no difference in activation of NMDA receptors in the $2 \mathrm{~N}$ and Ts65Dn DG. Open bar, 2N; filled bar, Ts65Dn. Error bars indicate SEM. C, LTP was normal in the Ts65Dn DG after suppressing inhibition with picrotoxin. Top, Representative responses recorded from slices of $2 \mathrm{~N}$ and Ts65Dn mice before (CON) and 50 min after (LTP) tetanization (thin and thick lines, respectively) in ACSF containing 100 $\mu \mathrm{m}$ picrotoxin. Vertical lines 1 and 2 indicate the linear parts of the responses used to measure the initial slopes. Note the increase in the initial slopes in both $2 \mathrm{~N}$ and Ts65Dn mice. Each curve represents an average of five consecutive responses. Arrowheads denote the stimulus artifacts, shown truncated. Bottom, Time course of the averaged initial slopes. A single tetanization train (arrow; Tet) evoked stable LTP in both the $2 \mathrm{~N}$ and Ts65Dn DG (open and filled circles, respectively).

inhibition, which restricts synaptic activation of NMDA receptors, is the cause for the failure to induce LTP in Ts65Dn slices.

\section{Decreased responses during tetanus in Ts65Dn slices}

If increased inhibition is responsible for failed induction of LTP, it should be possible to detect a difference in the response to tetanic stimulation in Ts65Dn slices. To test this idea, we performed experiments under the conditions used in Figure 2 for eliciting LTP in which we either did or did not block the NMDA receptor-mediated current. We recorded during the entire train of stimuli (i.e., 100 stimuli over $1 \mathrm{sec}$ ) while recording in ACSF or in ACSF containing $100 \mu \mathrm{M}$ DL-APV. The responses for $2 \mathrm{~N}$ and Ts65Dn ( $n=4$ slices each) were defined as the area under the curve after stimuli. The first measure examined was the area under the curve for the response to only the first stimulus. There was 


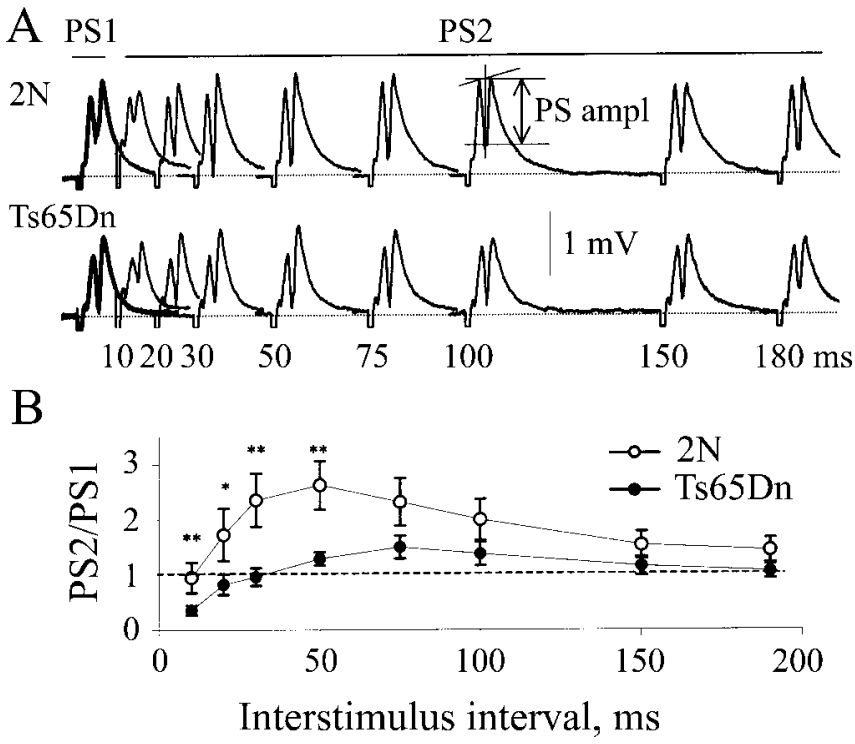

Figure 5. Enhanced paired-pulse depression of the population spike in the Ts65Dn DG. A, Representative field responses recorded in the granule cell layer of slices from $2 \mathrm{~N}$ and Ts65Dn mice (top and bottom panels, respectively). Interstimulus intervals varying from 10 to $180 \mathrm{msec}$ (as denoted by the numbers under the curves) were used. The responses to the first and the second stimulus of each pair [population spike 1 (PS1) and PS2] are shown in the thick and thin lines, respectively. The population spike amplitude (PS ampl) was measured as indicated. The reduction of the population spike amplitude at short interstimulus intervals reflects PPD. $B$, Ratio of the amplitudes of PS2 to PS1 as a function of the interstimulus interval in $2 \mathrm{~N}$ (open circles) and Ts65Dn (filled circles). At short intervals ( $<50 \mathrm{msec}$ ), the ratio was significantly smaller in the Ts65Dn than in the $2 \mathrm{~N} D$, signifying greater PPD of the population spike in Ts65Dn. ${ }^{*} p<0.05 ;{ }^{* *} p<0.03$. Error bars represent SEM.

no significant difference between $2 \mathrm{~N}$ and Ts65Dn slices in response to the first stimulus $(2 \mathrm{~N}, 7.5 \pm 1.4 \mathrm{msec} \cdot \mathrm{mV}$; Ts65Dn, $5.7 \pm 2.2 \mathrm{msec} \cdot \mathrm{mV} ; p=0.23$; the Mann-Whitney $U$ test), a result consistent with the findings in Figure 1. The second measure was the total areas under the curves for the responses to the first stimulus plus every fifth stimulus through the entire train (i.e., through 100 stimuli). These data showed a significant decrease in Ts65Dn slices $(2 \mathrm{~N}, 41.1 \pm 5.2 \mathrm{msec} \cdot \mathrm{mV}$; Ts65Dn, $26.2 \pm 6.6 \mathrm{msec} \cdot \mathrm{mV} ; p<0.02)$. The results for the experiments in ACSF containing DL-APV showed the same pattern. Thus, although there was no difference between the responses to the first stimulus $(2 \mathrm{~N}, 6.7 \pm 1.6 \mathrm{msec} \cdot \mathrm{mV}$; Ts65Dn, $5.3 \pm 2.1$ $\mathrm{msec} \cdot \mathrm{mV} ; p=0.3)$, the summed stimuli showed a significantly smaller response in Ts65Dn slices $(2 \mathrm{~N}, 36.2 \pm 6.5 \mathrm{msec} \cdot \mathrm{mV}$; Ts65Dn, $19.7 \pm 9.2 \mathrm{msec} \cdot \mathrm{mV} ; p<0.04)$. To further define the effect of inhibition, we attempted to record the responses during the tetanic stimulation from slices in the presence of the $\mathrm{GABA}_{\mathrm{A}}$ receptor antagonist picrotoxin. However, we could not make accurate measurements in this condition because the tetanic stimulation produced epileptiform activity in both $2 \mathrm{~N}$ and Ts65Dn slices.

The decreased responses in Ts65Dn slices during the tetanus are consistent with increased inhibition leading to decreased depolarization. They support the view that increased inhibition is a cause for failed induction of LTP. Furthermore, in showing that a difference between $2 \mathrm{~N}$ and Ts65Dn slices persists even when the NMDA receptor-mediated current is suppressed, they are evidence that increased inhibition is not driven by NMDA receptors.

Enhanced inhibition in the dentate gyrus of Ts65Dn mice To directly address the hypothesis that inhibitory synaptic transmission is enhanced in the dentate gyrus of Ts65Dn mice, we first
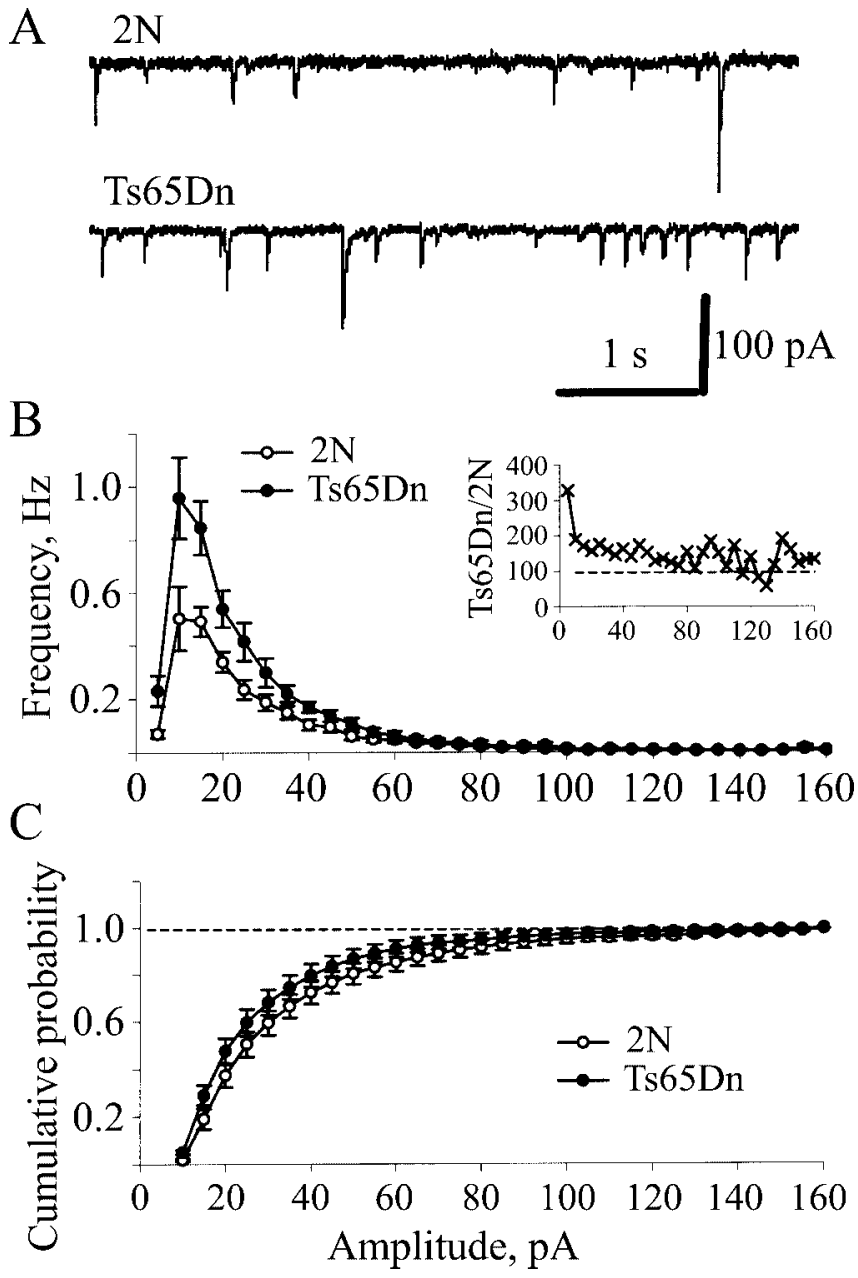

Figure 6. The frequency of miniature IPSCs was increased in the Ts65Dn DG. A, Examples of mIPSCs recorded from granule cells in slices from $2 \mathrm{~N}$ and $\mathrm{Ts65Dn}$ mice. $B$, Frequency histograms of mIPSC amplitudes in the DG of 2N (open circles) and Ts65Dn mice (filled circles). Inset, Ratio of mIPSC frequencies in the Ts65Dn and 2N DG as a function of mIPSC amplitude. Note that the increase of mIPSC frequency in Ts65Dn was primarily independent of mIPSC amplitude. C, Cumulative histogram of mIPSC amplitude. No difference was noted between the $2 \mathrm{~N}$ and Ts65Dn DG. Open circles, 2N; filled circles, Ts65Dn. The error bars in $B$ and C represent SEM.

examined paired-pulse depression (PPD) of the population spike, which is attributable in large part to feedback inhibition (Barnes, 1979; Adamec et al., 1981). Pairs of stimuli with an interstimulus interval ranging from 10 to $180 \mathrm{msec}$ were administered to the MML, and evoked population responses were recorded in the granule cell layer (Fig. 5A). At interstimulus intervals from 10 to $50 \mathrm{msec}$, there was a reduction in the ratio of the amplitudes of the second to the first population spikes (PS2/ PS1) in Ts65Dn slices $(n=9)$ compared with $2 \mathrm{~N}(n=10)$ slices $(p<0.05$ ) (Fig. $5 B$ ). This suggests that there is significantly stronger feedback inhibition in Ts65Dn mice.

We next recorded mIPSCs from DG granule cells of $2 \mathrm{~N}$ and Ts65Dn slices using whole-cell voltage-clamp recordings from slices perfused with ACSF containing NBQX (1 $\mu \mathrm{M})$, DL-APV (25 $\mu \mathrm{M})$, and TTX $(1 \mu \mathrm{M})$. Under these conditions, all of the events were blocked by picrotoxin (100 $\mu \mathrm{M}$; data not shown), confirming that mIPSCs were being recorded. The frequency of mIPSCs was significantly higher in Ts65Dn slices compared with $2 \mathrm{~N}$ slices (Fig. 6A,B) (average frequency, 2N, $2.53 \pm 0.36 \mathrm{~Hz} ; n=8$; Ts65Dn, $4.68 \pm 0.55 \mathrm{~Hz} ; n=9 ; p<0.01$ ), an effect that was most obvious for the more frequent, smaller amplitude mIPSCs (Fig. 
A
$2 \mathrm{~N}$

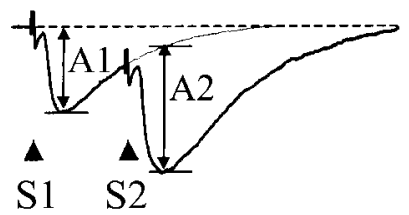

$\mathrm{B}$

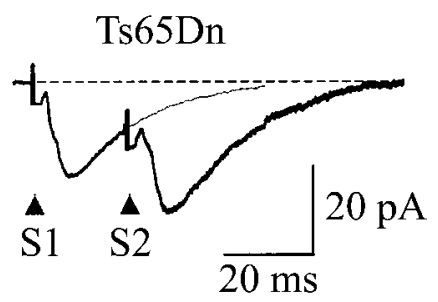

1998; Escorihuela et al., 1998; Sago et al., 2000; Hyde and Crnic, 2001; Hyde et al., 2001; Hunter et al., 2003).

We found that LTP, a model of synaptic plasticity that may engage similar cellular alterations to those occurring during learning and memory (Malenka and Nicoll, 1999; Morris et al., 2003), could not be elicited in the DG of Ts65Dn mice. Similar observations have been made in the CA1 region of these mice (Siarey et al., 1997, 1999), although the mechanisms underlying this deficit were not elucidated. Because many potential abnormalities in circuit and synaptic function as well as in intracellular signaling cascades can be evoked to explain a failure to induce LTP (Malenka and Nicoll, 1999), we performed a series of experiments to determine whether the core mechanisms responsible for LTP were impaired in Ts65Dn mice. Our results suggest that enhanced inhibitory synaptic transmission is the primary cause of the failure to induce LTP in the Ts65Dn DG. Several lines of evidence support this conclusion. First, suppression of $\mathrm{GABA}_{\mathrm{A}}$ receptor-mediated inhibition with picrotoxin restored both the NMDA receptor-mediated component of fEPSPs and induction of LTP in Ts65Dn slices. Second, increased paired-pulse depression of the population spike was observed, suggesting enhanced efficiency of feedback inhibition. Third, increased frequency of mIPSCs and decreased PPF of evoked IPSCs occurred in the Ts65Dn mice, findings consistent with an increase in the probability of GABA release from presynaptic terminals of inhibitory fibers. Importantly, the restoration of apparently normal LTP by blocking inhibition with picrotoxin suggests that the molecular mechanisms responsible for this form of synaptic plasticity are primarily preserved in the DG of Ts65Dn mice. Thus, although the tetanization protocol we used failed to induce LTP in Ts65Dn slices, it is possible that other patterns of tetanization could be effective.

Enhanced inhibition in the Ts65Dn hippocampus would appear to be discordant with the known propensity of DS individuals to develop epilepsy (Stafstrom, 1993). However, the mechanisms responsible for producing the epileptic state in DS have received little attention. Although increased inhibition might be expected to suppress the intrinsic activity of excitatory circuits, thus reducing the risk of epilepsy, alternatives can be envisioned in which increased inhibition predisposes to seizures and to the development of epilepsy. Indeed, enhanced inhibition has been observed in both animal models of epilepsy and in human epilepsy (Engel, 1996; Swanson et al., 1998). Additional studies will be needed to address the properties of excitatory and inhibitory circuits within the hippocampus and to examine the possibility that increased inhibition is linked to epilepsy.

It will be important to explore the structure and function of GABAergic circuits in the Ts65Dn hippocampus. Several types of GABAergic interneurons are present in the DG. Whether or not their number or activity is changed in Ts65Dn mice is unknown. Of note, the enhancement of the feedback inhibition, which depends on perisomic basket cells, suggests alterations in this population of interneurons. Consistent with this suggestion, Hill et al. (2003) found that vasoactive intestinal peptide, a marker of perisomic GABAergic basket interneurons (Freund and Buzsaki, 1996), is significantly overexpressed in Ts65Dn mice.

Additional work must also examine the molecular mechanisms responsible for the changes in GABA release from presynaptic terminals. The protein products of several genes present in the triplicated segment of chromosome 16 could, in theory, contribute to this abnormal synaptic function. For example, synaptojanin 1, a polyphosphoinositide phosphatase, is involved in uncoating of clathrin-coated vesicles and in the downregulation 
of actin polymerization at endocytic zones (Slepnev and De Camilli, 2000). Similarly, intersectin 1 is a scaffolding protein that interacts with a number of proteins needed either for clathrinmediated endocytosis or for actin assembly (O'Bryan et al., 2001; Schafer, 2002) and appears to link membrane-trafficking events with downstream signaling. Grik1, the gene encoding the GluR5 (glutamate receptor 5) subunit of kainate receptors, is also present in three copies in Ts65Dn. Indeed, the level of Grik1 mRNA is increased by $\sim 50 \%$ in the hippocampus of Ts65Dn mice (S. Selwood, unpublished observations). GluR5-containing receptors are present in GABAergic neurons within the hippocampus (Paternain et al., 2000), and selective activation of these receptors increases inhibition in CA1 (Cossart et al., 1998; Frerking et al., 1998). Thus, overexpression of GluR5 in the DG could also contribute to the increased inhibition in Ts65Dn mice. Finally, cholinergic synapses within the hippocampus of Ts65Dn mice are abnormal (Cooper et al., 2001). Because cholinergic afferents to the DG may suppress inhibitory neurons (Bilkey and Goddard, 1985), dysfunction of cholinergic terminals could reduce constraints on activation of inhibitory inputs.

All individuals with DS develop the neuropathology of Alzheimer's disease (AD) (Wisniewski et al., 1985), and many such patients develop increasing problems with learning and memory in later life (Chapman and Hesketh, 2000). A key aspect of the neuropathology of both $\mathrm{DS}$ and $\mathrm{AD}$ is the presence of neuritic plaques containing the $\mathrm{A} \beta$ ( $\beta$-amyloid) peptide, a product of the amyloid precursor protein (APP). The gene for APP is present in three copies in both human DS patients and in Ts65Dn mice. Moreover, mutated forms of the APP gene are responsible for autosomal dominant AD (for review, see Auld et al., 1998). Similar to $\mathrm{AD}$, there are abnormalities in the cholinergic system of DS subjects and in Ts65Dn mice (Cooper et al., 2001). Finally, as in Ts65Dn mice, in mouse models of AD, there are reports of reduced synaptic plasticity and impaired LTP (Cullen et al., 1997; Chapman et al., 1999; Dewachter et al., 2000; Kamenetz et al., 2003). However, we know of no evidence that increased inhibitory neurotransmission plays a role in these models. Also, it is important to note that, although AD models show increased levels of $A \beta$, there is no increase in $A \beta$ in the Ts65Dn brain (A. Salehi, W. Xia, W. Mobley, unpublished observations). This indicates that increased levels of this peptide do not mediate the changes in synaptic plasticity or in cholinergic parameters seen in Ts65Dn mice

The suppression of LTP induction that arises from increased inhibition in the DG could contribute significantly to the deficits in learning and memory detected in both Ts65Dn mice and in individuals with DS. Potential strategies for enhancing cognitive function in DS individuals could therefore, in theory, focus on normalizing inhibition. Although it does not underestimate the complex biological issues that attend overexpression of $>300$ genes found on chromosome 21 , the current study provides hope that it will be possible to discern mechanisms that play a role in the abnormal cognitive functions regulated by the hippocampus in DS. The elucidation of both the genetic and cellular bases for enhanced inhibition in the Ts65Dn hippocampus is a critical next step.

\section{References}

Adamec RE, McNaughton B, Racine R, Livingston KE (1981) Effects of diazepam on hippocampal excitability in the rat: action in the dentate area. Epilepsia 22:205-215.

Antonarakis SE, Lyle R, Chrast R, Scott HS (2001) Differential gene expression studies to explore the molecular pathophysiology of Down syndrome. Brain Res Brain Res Rev 36:265-274.
Auld DS, Kar S, Quirion R (1998) Beta-amyloid peptides as direct cholinergic neuromodulators: a missing link? Trends Neurosci 21:43-49.

Aylward EH, Li Q, Honeycutt NA, Warren AC, Pulsifer MB, Barta PE, Chan MD, Smith PD, Jerram M, Pearlson GD (1999) MRI volumes of the hippocampus and amygdala in adults with Down's syndrome with and without dementia. Am J Psychiatry 156:564-568.

Barnes CA (1979) Memory deficits associated with senescence: a neurophysiological and behavioral study in the rat. J Comp Physiol Psychol 93:74-104.

Bayazitov I, Kleschevnikov A (2000) Afferent high strength tetanizations favour potentiation of the NMDA vs. AMPA receptor-mediated component of field EPSP in CA1 hippocampal slices of rats. Brain Res 866:188-196.

Bilkey DK, Goddard GV (1985) Medial septal facilitation of hippocampal granule cell activity is mediated by inhibition of inhibitory interneurones. Brain Res 361:99-106.

Carlesimo GA, Marotta L, Vicari S (1997) Long-term memory in mental retardation: evidence for a specific impairment in subjects with Down's syndrome. Neuropsychologia 35:71-79.

Chapman PF, White GL, Jones MW, Cooper-Blacketer D, Marshall VJ, Irizarry M, Younkin L, Good MA, Bliss TV, Hyman BT (1999) Impaired synaptic plasticity and learning in aged amyloid precursor protein transgenic mice. Nat Neurosci 2:271-276.

Chapman RS, Hesketh LJ (2000) Behavioral phenotype of individuals with Down syndrome. Ment Retard Dev Disabil Res Rev 6:84-95.

Cooper JD, Salehi A, Delcroix JD, Howe CL, Belichenko PV, Chua-Couzens J, Kilbridge JF, Carlson EJ, Epstein CJ, Mobley WC (2001) Failed retrograde transport of NGF in a mouse model of Down's syndrome: reversal of cholinergic neurodegenerative phenotypes following NGF infusion. Proc Natl Acad Sci USA 98:10439-10444.

Cossart R, Esclapez M, Hirsch JC, Bernard C, Ben-Ari Y (1998) GluR5 kainate receptor activation in interneurons increases tonic inhibition of pyramidal cells. Nat Neurosci 1:470-478.

Cullen WK, Suh YH, Anwyl R, Rowan MJ (1997) Block of LTP in rat hippocampus in vivo by beta-amyloid precursor protein fragments. NeuroReport 8:3213-3217.

Davisson MT, Schmidt C, Akeson EC (1990) Segmental trisomy of murine chromosome 16: a new model system for studying Down syndrome. Prog Clin Biol Res 360:263-280.

Davisson MT, Schmidt C, Reeves RH, Irving NG, Akeson EC, Harris BS, Bronson RT (1993) Segmental trisomy as a mouse model for Down syndrome. Prog Clin Biol Res 384:117-133.

Demas GE, Nelson RJ, Krueger BK, Yarowsky PJ (1996) Spatial memory deficits in segmental trisomic Ts65Dn mice. Behav Brain Res 82:85-92.

Demas GE, Nelson RJ, Krueger BK, Yarowsky PJ (1998) Impaired spatial working and reference memory in segmental trisomy (Ts65Dn) mice. Behav Brain Res 90:199-201.

Dewachter I, van Dorpe J, Spittaels K, Tesseur I, Van Den Haute C, Moechars D, Van Leuven F (2000) Modeling Alzheimer's disease in transgenic mice: effect of age and of presenilin1 on amyloid biochemistry and pathology in APP/London mice. Exp Gerontol 35:831-841.

Dierssen M, Fillat C, Crnic L, Arbones M, Florez J, Estivill X (2001) Murine models for Down syndrome. Physiol Behav 73:859-871.

Engel Jr J (1996) Excitation and inhibition in epilepsy. Can J Neurol Sci 23:167-174.

Epstein CJ (2002) 2001 William Allan Award Address. From Down syndrome to the "human" in "human genetics." Am J Hum Genet 70:300-313.

Escorihuela RM, Vallina IF, Martinez-Cue C, Baamonde C, Dierssen M, Tobena A, Florez J, Fernandez-Teruel A (1998) Impaired short- and longterm memory in Ts65Dn mice, a model for Down syndrome. Neurosci Lett 247:171-174.

Frerking M, Malenka RC, Nicoll RA (1998) Synaptic activation of kainate receptors on hippocampal interneurons. Nat Neurosci 1:479-486.

Freund TF, Buzsaki G (1996) Interneurons of the hippocampus. Hippocampus 6:347-470.

Galdzicki Z, Siarey R, Pearce R, Stoll J, Rapoport SI (2001) On the cause of mental retardation in Down syndrome: extrapolation from full and segmental trisomy 16 mouse models. Brain Res Brain Res Rev 35:115-145.

Gardiner K, Fortna A, Bechtel L, Davisson MT (2003) Mouse models of Down syndrome: how useful can they be? Comparison of the gene con- 
tent of human chromosome 21 with orthologous mouse genomic regions. Gene 318:137-147.

Hill JM, Ades AM, McCune SK, Sahir N, Moody EM, Abebe DT, Crnic LS, Brenneman DE (2003) Vasoactive intestinal peptide in the brain of a mouse model for Down syndrome. Exp Neurol 183:56-65.

Holtzman DM, Santucci D, Kilbridge J, Chua-Couzens J, Fontana DJ, Daniels SE, Johnson RM, Chen K, Sun Y, Carlson E (1996) Developmental abnormalities and age-related neurodegeneration in a mouse model of Down syndrome. Proc Natl Acad Sci USA 93:13333-13338.

Hunter CL, Bimonte HA, Granholm AC (2003) Behavioral comparison of 4 and 6 month-old Ts65Dn mice: age-related impairments in working and reference memory. Behav Brain Res 138:121-131.

Hyde LA, Crnic LS (2001) Age-related deficits in context discrimination learning in Ts65Dn mice that model Down syndrome and Alzheimer's disease. Behav Neurosci 115:1239-1246.

Hyde LA, Frisone DF, Crnic LS (2001) Ts65Dn mice, a model for Down syndrome, have deficits in context discrimination learning suggesting impaired hippocampal function. Behav Brain Res 118:53-60.

Kamenetz F, Tomita T, Hsieh H, Seabrook G, Borchelt D, Iwatsubo T, Sisodia S, Malinow R (2003) APP processing and synaptic function. Neuron 37:925-937.

Korenberg JR, Chen XN, Schipper R, Sun Z, Gonsky R, Gerwehr S, Carpenter N, Daumer C, Dignan P, Disteche C (1994) Down syndrome phenotypes: the consequences of chromosomal imbalance. Proc Natl Acad Sci USA 91:4997-5001.

Krasuski JS, Alexander GE, Horwitz B, Rapoport SI, Schapiro MB (2002) Relation of medial temporal lobe volumes to age and memory function in nondemented adults with Down's syndrome: implications for the prodromal phase of Alzheimer's disease. Am J Psychiatry 159:74-81.

Kurt MA, Davies DC, Kidd M, Dierssen M, Florez J (2000) Synaptic deficit in the temporal cortex of partial trisomy 16 (Ts65Dn) mice. Brain Res 858:191-197.

Malenka RC, Nicoll RA (1999) Long-term potentiation-a decade of progress? Science 285:1870-1874.

Morris RG, Moser EI, Riedel G, Martin SJ, Sandin J, Day M, O'Carroll C (2003) Elements of a neurobiological theory of the hippocampus: the role of activity-dependent synaptic plasticity in memory. Philos Trans R Soc Lond B Biol Sci 358:773-786.

Moyer Jr JR, Brown TH (1998) Methods for whole-cell recording from visually preselected neurons of perirhinal cortex in brain slices from young and aging rats. J Neurosci Methods 86:35-54.

O’Bryan JP, Mohney RP, Oldham CE (2001) Mitogenesis and endocytosis: what's at the INTERSECTIoN? Oncogene 20:6300-6308.

Paternain AV, Herrera MT, Nieto MA, Lerma J (2000) GluR5 and GluR6 kainate receptor subunits coexist in hippocampal neurons and coassemble to form functional receptors. J Neurosci 20:196-205.

Pennington BF, Moon J, Edgin J, Stedron J, Nadel L (2003) The neuropsychology of Down syndrome: evidence for hippocampal dysfunction. Child Dev 74:75-93.

Pinter JD, Brown WE, Eliez S, Schmitt JE, Capone GT, Reiss AL (2001) Amygdala and hippocampal volumes in children with Down syndrome: a high-resolution MRI study. Neurology 56:972-974.

Reeves RH, Irving NG, Moran TH, Wohn A, Kitt C, Sisodia SS, Schmidt C, Bronson RT, Davisson MT (1995) A mouse model for Down syndrome exhibits learning and behaviour deficits. Nat Genet 11:177-184.

Reeves RH, Baxter LL, Richtsmeier JT (2001) Too much of a good thing: mechanisms of gene action in Down syndrome. Trends Genet 17:83-88.

Roizen NJ, Patterson D (2003) Down's syndrome. Lancet 361:1281-1289.

Saal D, Dong Y, Bonci A, Malenka RC (2003) Drugs of abuse and stress trigger a common synaptic adaptation in dopamine neurons. Neuron 37:577-582.

Sago H, Carlson EJ, Smith DJ, Rubin EM, Crnic LS, Huang TT, Epstein CJ (2000) Genetic dissection of region associated with behavioral abnormalities in mouse models for Down syndrome. Pediatr Res 48:606-613.

Schafer DA (2002) Coupling actin dynamics and membrane dynamics during endocytosis. Curr Opin Cell Biol 14:76-81.

Siarey RJ, Stoll J, Rapoport SI, Galdzicki Z (1997) Altered long-term potentiation in the young and old Ts65Dn mouse, a model for Down syndrome. Neuropharmacology 36:1549-1554.

Siarey RJ, Carlson EJ, Epstein CJ, Balbo A, Rapoport SI, Galdzicki Z (1999) Increased synaptic depression in the Ts65Dn mouse, a model for mental retardation in Down syndrome. Neuropharmacology 38:1917-1920.

Slepnev VI, De Camilli P (2000) Accessory factors in clathrin-dependent synaptic vesicle endocytosis. Nat Rev Neurosci 1:161-172.

Stafstrom CE (1993) Epilepsy in Down syndrome: clinical aspects and possible mechanisms. Am J Ment Retard 98:12-26.

Swanson TH, Sperling MR, O'Connor MJ (1998) Strong paired pulse depression of dentate granule cells in slices from patients with temporal lobe epilepsy. J Neural Transm 105:613-625.

Sylvester PE (1983) The hippocampus in Down's syndrome. J Ment Defic Res 27:227-236.

Vicari S, Bellucci S, Carlesimo GA (2000) Implicit and explicit memory: a functional dissociation in persons with Down syndrome. Neuropsychologia 38:240-251.

Wisniewski KE, Wisniewski HM, Wen GY (1985) Occurrence of neuropathological changes and dementia of Alzheimer's disease in Down's syndrome. Ann Neurol 17:278-282.

Zucker RS (1989) Short-term synaptic plasticity. Annu Rev Neurosci 12:13-31. 